\title{
Business Strategy Formulation for Publishing Company (Case Study: ABC Press)
}

\author{
Aulia Widya Bestari Wibisono and Deddy Priatmodjo Koesrindartoto
}

\begin{abstract}
With emergence of technological and social change, rivalry between firms in the publishing industry is becoming more intense. Number of publishers in Indonesia keeps increasing, while switching cost of customer is low. ABC Press is a university publisher that has a volatile revenue, where they experienced revenue decrease in 2016 by $1,73 \%$ and in 2019 by $19,36 \%$. Besides that, the business also has not grown much, where the average revenue growth from 2015 to 2019 is only $15,93 \%$. ABC Press needs to formulate and reinvent their business strategy and model to improve their performance, remain competitive and sustainable in the publishing industry. This study uses primary data based on interview with three representatives of $\mathrm{ABC}$ Press and examine related secondary data to map the current Business Model Canvas (BMC). Then internal and external analysis is carried out to perform SWOT analysis in BMC, followed by strategy and new BMC formulation. To create value innovation, author used Four Action Framework in the strategy formulation. Cost leadership is deemed as the most appropriate business strategy, which demands ABC Press to conduct process innovation through developed production and distribution methods. Meanwhile, long tail business model combined with multi-sided platform is the appropriate business model, where ABC Press needs to focus on offering large range of niche products through their website as their main platform.
\end{abstract}

Index Terms - Publishing industry, business strategy, business model, Four Action Framework.

\section{INTRODUCTION}

Technology is increasingly becoming a big force for business change. With the effect of mobile developments, business models are being challenged and companies are facing the challenge of business model change [1]. Internet users in Indonesia keeps increasing from year to year. In 2018-2023 period, it is projected that it will increase with an average growth of $10,2 \%$ [2]. This phenomenon has generated lifestyle changes. Just like in other sectors, the combined effects of globalization, emerging technology, and an increasingly changing market are addressing significant changes in book publishing [3]. Nowadays, competition in the publishing industry keeps getting more intense, especially with the low customer switching cost. Number of publishers in Indonesia has reached 1.655 publishers, and since 2010 the number has kept increasing [4]. In addition to competition for authors and readers, it has extended to competition in providing access to as many platforms as possible, including tablets and eBook to smartphones and computer [5]. Combined with the maturation of e-commerce technologies for purchase, sales, and distribution, the book publishing industry is in a position to take advantage of global, 24x7 networks, and wide choices of hardware and software technologies (or threaten) to develop in back and front-end processes, markets and platforms, value chains and business models [6]. ABC Press is one of the players in the publishing industry which mainly focuses in publishing academic books for university students. Unfortunately, their revenue stream is volatile and the average revenue growth in five years is considered small. ABC Press has to contend with thousands of other publishers that competes to become a leader in the industry by offering different innovations. In order to keep pace with developments in the industry and to gain competitive advantage, ABC Press needs to formulate their business strategy and reinvent their business model.

\section{Methodology}

Qualitative method is used in this study, by utilizing primary and secondary data. Primary data is generated from interview with Director, Head of Marketing, and Head of Financial Accounting as representatives of ABC Press. Meanwhile secondary data is obtained from company report, and other relevant publication, literature, and news. Mapping current Business Model Canvas (BMC) is the first step in the study analysis, followed by internal and external analysis. Resource and value chain analysis is used in internal analysis. Meanwhile, the external analysis is conducted using business model external environment and benchmarking analysis. Based on both, internal and external analysis, SWOT analysis is generated toward the current BMC. Followed by strategy formulation and proposed Business Model Canvas.

\section{FINDINGS}

Business issue analysis of ABC Press is breakdown in three parts, which are mapping their current BMC, analyzing their internal and external factors.

\section{A. Current Business Model Canvas Mapping}

Business model is characterized as a business implementation method in which a company can sustain itself, such as generate revenue [7]. It is important because it offers a new idea that enables a company to gain competitive advantages [8]. By developing a business model, managers

Published on September 30, 2020.

Aulia Widya Bestari Wibisono, Bandung Institute of Technology, Indonesia. (email: aulia.widya ${ }^{\circledR}$ sbm-itb.ac.id)

Deddy Priatmodjo Koesrindartoto, Bandung Institute of Technology, Indonesia.

(email: deddypri@ ${ }^{@}$ sbm-itb.ac.id) 
can quickly develop plans for strategy implementation [9]. Business Model Canvas is a proposed strategic management tool which is built of nine main elements [10]. Based on analysis, below is the current BMC of ABC Press.

TABLE I: CURRENT Business MOdEL CANVAS

\begin{tabular}{|c|c|c|}
\hline No & Building Blocks & Explanation \\
\hline 1 & Value Proposition & $\begin{array}{l}\text { - Performance (Excellent editorial } \\
\text { competencies) } \\
\text { - } \text { Customization of product and services }\end{array}$ \\
\hline 2 & Customer Segment & Students and lecturers of $\mathrm{ABC}$ \\
\hline 3 & Channels & $\begin{array}{l}\text { E-commerce (Website), bookstore, } \\
\text { marketplace (Tokopedia) }\end{array}$ \\
\hline 4 & $\begin{array}{l}\text { Customer } \\
\text { Relationship }\end{array}$ & Personal assistance \\
\hline 5 & Revenue Stream & $\begin{array}{l}\text { Book and dictate sales, publishing and } \\
\text { printing services }\end{array}$ \\
\hline 6 & Key Resources & Physical, intellectual, employee, financial \\
\hline 7 & Key Partnership & $\begin{array}{l}\text { Supplier of raw materials, Astagraphia, } \\
\text { DKV FSRD, Pos Indonesia, UPT Bahasa, } \\
\text { X coffee shop }\end{array}$ \\
\hline 8 & Key Activities & $\begin{array}{l}\text { Designing, producing, distributing, } \\
\text { marketing }\end{array}$ \\
\hline 9 & Cost Structure & $\begin{array}{l}\text { Cost of goods sold, operation expense, } \\
\text { marketing expense }\end{array}$ \\
\hline
\end{tabular}

\section{B. Internal Analysis}

Internal analysis is generated to determine strength and weakness of the company. It will be conducted using resources and value chain activity analysis. In resources analysis there are tangible and intangible resources that is owned by a company. Tangible resources can be tracked and calculated, meanwhile intangible resources are embedded in company's history, which is accumulated over time, and relatively difficult for rivals to replicate. Meanwhile value chain activities are activities carried out by a company to manufacture products, then to sell, distribute and service those products in ways that create value for customers. It consists primary and support activity [11].

Tangible resources consist of financial, organizational, physical, and technological resources. For financial resources, $\mathrm{ABC}$ Press finance their operation from profit they generate from sales and services offered. They do not receive funding from their university, and cannot receive grants because of their company status, that is why the company wants to be a limited liability company. As for performance, they have experienced a decline of revenue in 2016 by $1,73 \%$ and 2019 by $19,36 \%$ caused by volatility of demand towards their product and services. As for organizational resources, the company has four main divisions (publishing, printing, commercial, and financial accounting) and has plans to add a digital division, but they still lack required human resource. In terms of physical resources, the company still lack of adequate machinery and their bookstore location has several disadvantages. Since, the bookstore is located inside campus, there is time limitation of opening hours and it is hard for potential customers to recognize them. Meanwhile for technological resources, they own an offset machine, several channels such as website and Tokopedia account, also they have several social media accounts (Instagram, Twitter, Facebook) that help them distribute and promote their product and services.

Intangible resources consist of human, innovation, and reputational resources. In terms of human resources, they act as the company key resources since the company offers product and services that needs particular capabilities. ABC Press has 30 employees, where the most important position is owned by the editor and financial accounting division. ABC Press is famous for their editor performance, where they can produce more than 100 title of books per month, when other university publishers can only produce around 30 titles. But the company still lack human resources in the field of digital marketing and IT. As for innovation, ABC Press still lack adequate resources to innovate. Their plan is to develop digital marketing and eBooks. Meanwhile for reputational resources, the company still gets complaints from customers, since the company is lacking in the production process, specifically the quality control process. Besides that, the company also has a weak brand, since even many students of the university are unaware of the existence of the company.

Based on the value chain activity analysis, the primary activity that is analyzed consist of inbound logistics, operations, out bond logistics, marketing and sales, and services. In terms of inbound logistics, ABC Press build great relationship with their suppliers, but as for inventory the company has a high number of slow-moving inventories. For operations, the company is still lacking in the quality control process, which can be bad for the company's reputation. For out bond logistics, ABC Press have various channels for distribution such as their website, bookstore, and marketplace account (Tokopedia). For marketing and sales, the company is still lacking in the promotion program, since brand awareness towards their company is still low. For service, the company doesn't have activities that can increase customer relationship.

Support activities consist of firm infrastructure, procurement, human resource management, and technology management and development. For firm infrastructure, the company is built out of four main divisions. For procurement, the company applies supply chain management. Meanwhile for human resource management, they have developed their recruitment process which includes an internship and training program, but they do not have KPI (Key Performances Indicator) to measure employee performance. As for technology management and development, they run their own website and Tokopedia account, also have several social medias account such as Instagram, Twitter, and Facebook.

\section{External Analysis}

External analysis is conducted to discover opportunities and threats in macro, industry, and competitor environment to help develop a more competitive business model. External analysis will be done by doing business model external environment analysis and benchmarking analysis. Business model external environment analysis consists of market forces, industry forces, key trends and macroeconomic forces. Based on the market forces, the publishing industry is pushed by government to increase digital database. In 2016 to 2017 , only $2,5 \%$ internet users that use internet to access knowledge, this is mainly because number of digital based databases such as books that provides such information is relatively low. Genres that has the highest demand in the market are fiction novels, children books, and academic or 
school books. Besides that, with the development of technology, people lifestyles are starting to change, including learning system, and transaction patterns. But with millennials dominating the population by $33,75 \%$, it can be an opportunity to utilize technology, since this generation is frequently exposed to technology. Based on data from Global Web Index in 2019, Indonesia has the highest rate of ecommerce adoption, where $90 \%$ of internet users (age $16-$ 64 years) have purchased products and services online. As for the industry forces, the industry has medium attractiveness, where it still has profit potential. Based on the analysis, the industry has high bargaining power of buyers, medium threat of new entrants and substitute of product and services, also low bargaining power of supplier and competitive rivalry. Meanwhile for key trends, for the technology trends, there is a constant increase of internet users, the growth has reached $10,12 \%$, way over the population growth itself that is only $0,63 \%$ [12]. For regulatory trends, author is burdened by tax and copyright is a big issue in this industry. Copyright is regulated in Law Number 28 of 2014, but is hasn't been implemented the way it should be, seeing that number of piracies in Indonesia is still high. For societal and cultural trends, book enthusiast and ethics toward intellectual property rights is low, and there is a shift of behavior towards digitization. Meanwhile for socioeconomic trends, there is an increase of education and literacy rates. For millennial generation their average length of school is 10,04 years, while literacy numbers are $99,39 \%$, the number has increased from previous generations [13]. Whereas for macroeconomic forces, world economy has fallen during the pandemic caused by COVID-19. This affects the publishing industry, more than $50 \%$ publishers of IKAPI (The Indonesian Publishers Association) have had a decline of sales.

Benchmarking is an analysis that can be done within a company, or even could be external comparisons, it also can be towards unrelated business. It is an attempt to enhance processes in any way, to see if costs can be decreased, revenues can be improved, and customer loyalty can be enhanced [14]. Benchmarking is conducted towards other university publishers in Indonesia, publishers in world top universities, also leading self-publishers in the industry. Based on the analysis, advantages that they have is that they build website as their main platform for readers and authors to interact, they have low inventory since they use POD (Print on Demand) system. Besides that, they collaborate with third parties in production process and selling books, they build customer relationship through events such as author talks and book reviews, and they also do personalization to each customer by providing personalized book recommendation. Besides that, they offer a wide range of format, fields, and also genre published.

\section{RESULTS AND SOLUTION}

This section will explain about the strategy formulation which consists of business-level strategy, functional-level strategy, blue ocean strategy, followed by the proposed new BMC.

\section{A. Business-Level Strategy}

Business strategy is designed to improve market position and develop competitive advantages and practices to create strategic capabilities [15]. Currently, ABC Press implements the focused cost leadership strategy, where they target narrow market (students and lecturers of $\mathrm{ABC}$ ) and basic customer value tends to be finding the lowest cost. However, in implementing this strategy there are several risks, such as there can be competitor that can offer ABC Press customers the same service with lower price or add differentiation with the same price and needs of customers in a narrow segment can be similar to industry-wide customers over time [11]. ABC Press targets narrow but doesn't realize that there are substitute for their product and services. Besides that, the company has an excessive inventory of books. So, proposed business-level strategy is to implement cost leadership strategy, where the company needs to perform process innovation through developed production and distribution methods, so the company can run more efficiently.

\section{B. Functional-Level Strategy}

Based on SWOT analysis that has been conducted, TOWS Matrix will be generated to show how external opportunities and threats facing the publishing industry can be balanced by ABC Press internal strengths and weaknesses, resulting in four sets of potential strategic alternatives [16]. This tool is very useful for producing a variety of alternatives that may not have been considered by decision-makers of ABC Press. TOWS Matrix of ABC Press can be seen in the Table II.

\section{Blue Ocean Strategy}

To create competitive advantage in the industry, ABC Press should implement blue ocean strategy. Value innovation is essentially what blue ocean strategy is about. It is where the company improves value for customers by creating new benefits and services and at the same time reducing cost. Four Actions Framework is used as a tool to generate value innovation. There are four elements that is used in this framework, which are eliminate, reduce, raise, and create [10].

TABLE III: Four Actions Framework of ABC Press

\begin{tabular}{cl}
\hline \hline Eliminate & \multicolumn{1}{c}{ Raise } \\
\hline & - Range of product type, book genres and \\
& format \\
& - Partnership \\
& - Platform promotion, management, and \\
& maintenance \\
& - Skill full and experienced human \\
& resource \\
& - Brand name \\
& Channel \\
\hline Reduce & \\
\hline - Inventory & - Self-publishing services \\
- Marketing cost & Automated services for customers \\
& (Applying Customer Relationship \\
& Management) \\
& - Co-creation of customers \\
& Multi-sided platform \\
\hline
\end{tabular}


TABLE II: ABC Press TOWS Matrix

\begin{tabular}{|c|c|c|}
\hline & Strength & Weakness \\
\hline & $\begin{array}{l}\text { - Strong synergies between products } \\
\text { and services (S1) } \\
\text { - Revenue streams are diversified (S2) } \\
\text { - Key resources are difficult for } \\
\text { competitors to replicate (S3) } \\
\text { - Focused and work with partners when } \\
\text { necessary, also maintain good } \\
\text { relationship with key partners (S4) } \\
\text { - Several choices of channel (S5) }\end{array}$ & $\begin{array}{l}\text { - Still receiving complaint from customers (W1) } \\
\text { - Revenues are unpredictable and their sustainability is } \\
\text { questionable (W2) } \\
\text { - Revenues are transactional with few repeat purchases } \\
\text { (W3) } \\
\text { - Operation is cost-inefficient (W4) } \\
\text { - Lack of adequate resources (W5) } \\
\text { - Not all key activities are executed efficiently (W6) } \\
\text { - Efforts in acquiring new customers is still low (W7) } \\
\text { - Prospects fail to notice channels (W8) } \\
\text { - Weak customer relationship (W9) } \\
\text { - Brand is weak (W10) }\end{array}$ \\
\hline Opportunity & Strength - Opportunity (SO) & Weakness - Opportunity (WO) \\
\hline 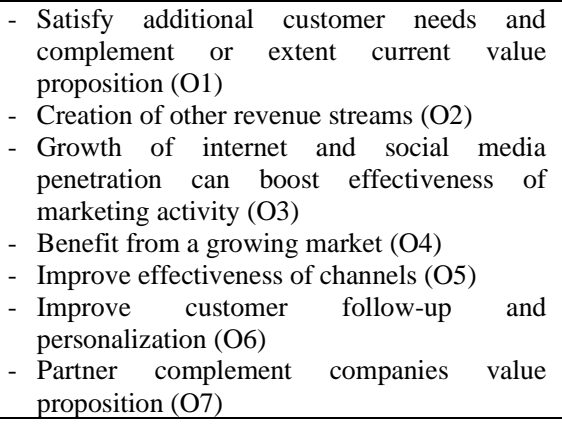 & $\begin{array}{l}\text { - Development of product and services } \\
\text { towards digitization }(\mathrm{S} 1, \mathrm{~S} 2, \mathrm{~S} 3, \mathrm{~S} 4 \\
\mathrm{O} 1, \mathrm{O} 2, \mathrm{O} 4, \mathrm{O} 7) \\
\text { - Create new channels to reach wider } \\
\text { market }(\mathrm{S} 4, \mathrm{~S} 5, \mathrm{O} 1, \mathrm{O} 4, \mathrm{O} 5, \mathrm{O} 7)\end{array}$ & $\begin{array}{l}\text { - Improve quality of product and services to increase } \\
\text { customer satisfaction (W1, W4, W6, O1, O7) } \\
\text { - Broaden genre variation that is published (W2, W3, } \\
\text { W7, O1, O2, O4, O6) } \\
\text { - Improve production process by using adequate } \\
\text { machinery, technology, and human resource (W1, } \\
\text { W4, W5, W6, O1, O7) } \\
\text { - Actively implementing digital marketing to increase } \\
\text { brand awareness (W7, W8, W9, W10, O3, O4, O6) } \\
\text { - Improve customer relationship (W1, W7, W9, O1, } \\
\text { O4, O6) }\end{array}$ \\
\hline Threat & Strength - Threat (ST) & Weakness - Threat (WT) \\
\hline $\begin{array}{l}\text { - Medium substitute of products and services } \\
\text { (T1) } \\
\text { - Competitor are threatening to offer better } \\
\text { value (T2) } \\
\text { - Margins are threatened by technology (T3) } \\
\text { - High bargaining power of buyers (T4) }\end{array}$ & $\begin{array}{l}\text { - Implement blue ocean strategy to } \\
\text { highly differentiate it from } \\
\text { competitors (S1, S3, S4, S5, T1, T2) } \\
\text { - Development of product and services } \\
\text { based on technology trend (S1, S2, } \\
\text { S3, S4, T3, T4) }\end{array}$ & $\begin{array}{ll}\text { - } & \text { Applying POD system (W2, W3, W4, T1, T2, T3) } \\
\text { - Establish Key Performance Indicator to maintain and } \\
\text { improve human resource performance (W1, W5, W6, } \\
\text { W7, W9, W10, T1, T2) }\end{array}$ \\
\hline
\end{tabular}

\section{Proposed New Business Model}

Business model is generated from business-level strategy. Cost leadership strategy that is chosen, is in line with inventory issues of ABC Press. The company has a high number of slow-moving inventories, causing a disadvantage for the company. Proposed new business model for ABC Press would be implementing the long tail business model pattern combined with multi-sided platform. Publishers acknowledged the fact that many books would not draw buyers, and only a limited number of titles would make it into backlists [17]. Multi-sided platform generates value by facilitating interaction between two different yet interdependent customer segments. Long tail business model is about selling less of more, concentrating on delivering a wide variety of niche products, each of which sells fairly infrequently [18]. A large number of products in the tail, compounded by a comparatively small number of sales of each, is equal to a very, very large number.

There are three economic causes that has given this trend a rise in the media industry [19]. The first is democratization of tools of production, ABC Press can generate a multi-sided platform and vary their product by collaborating with third parties. They can collaborate with tech and printing companies, so there is no need to invest in machinery with high cost. The second cause is democratization of distribution, $\mathrm{ABC}$ Press can utilize the internet for distribution through their website and various marketplace. By utilizing the internet, company can also conduct digital marketing that can reach wider range of customers. The third cause is the decreasing search cost to connect supply and demand. The provision of search engine by developing website and marketplace of $\mathrm{ABC}$ Press, can make the company understand items that are demanded by customers. Not only the hit items, but also non-hit items, opening opportunity for $\mathrm{ABC}$ Press to provide wide variety of choices. Besides that, ABC Press doesn't only provide wide choices, but also can help customers search items they want through sort of genre, price, date, ranks, and even by other customer reviews. Nine building blocks of the proposed BMC can be seen below.

\section{Value Proposition}

Proposed value proposition for ABC Press is convenience and accessibility, also customization. Convenience and accessibility are performed by providing self-publishing services through developed website. As for customization, ABC Press will provide wide varieties of product type, book genre, and format based on customer preference. ABC Press will develop their product and services, starting from selling high quality merchandise, offering services (printing, editing, designing) for photo books, comic books, even yearbooks. ABC Press won't only publish academic books, but other genres starting from fiction novels to children books will also be published by them. Besides that, they will also provide books in digital format (eBook).

\section{Customer Segment}

Proposed customer segment for ABC Press is niche market which consists niche content providers and niche customer segments. ABC Press will use its main platform, which is their website, to facilitate interaction between both customer segment. Because although they have different interest, but they still act as ABC Press customers. Niche content provider needs ABC Press services to publish their book, meanwhile niche customers will need information that is provided by niche content provider. 


\section{Channels}

Proposed channels for $\mathrm{ABC}$ Press in implementing the long tail business model are website, bookstore, and marketplaces. ABC Press already has a website, but it hasn't been able to perform as a multi-sided platform. So, there should be a development of website. Besides that, ABC Press already has a Tokopedia account as their marketplace channel, but $\mathrm{ABC}$ Press can add several channels such as Bukalapak, Shopee, Lazada, and Google Play Books. Bukalapak, Shopee, and Lazada are chosen because they are most accessed marketplace in Indonesia besides Tokopedia [12]. Meanwhile Google Play Books is chosen to facilitate the distribution of eBook as ABC Press additional format. Meanwhile for their bookstore, the company can develop it to a coffeeshop concept. So not only customers can buy books, but they can also enjoy food and beverages at the bookstore, also buy products offered, such as merchandise.

\section{Customer Relationship}

Proposed customer relationship for ABC Press are personal assistance, automated services, and co-creation. Personal assistance will be implemented in the bookstore during transactions with customers, including the after service. Automated service will be implemented by applying Customer Relationship Management. Meanwhile co-creation will be done by gathering customers to create reviews as content that can be read by public.

\section{Revenue Streams}

Revenue streams of proposed business model will be generated through asset sales and usage fee. Asset sales will be obtained from sales of various product type created. By using the business model, ABC Press will create book in physical and digital format with wide variety of genres, and also sell high quality merchandise of $\mathrm{ABC}$. As for usage fee, $\mathrm{ABC}$ Press will offer services such as publishing, printing, editing, and also designing books, photo book, comic book, magazine, and also yearbooks. With the development of store becoming a coffeeshop concept, it can also generate revenue from food and beverage sales.

\section{Key Resources}

There is an additional of website, relationships, networks, and loyalty in the key resources proposed. Website will be used as the company's main platform. Relationship and network are part of intellectual resources that can be used by $\mathrm{ABC}$ Press in expanding their business and making sure their business runs efficiently. Meanwhile loyalty is expected from key partners, and also customers.

\section{Key Partnership}

Proposed key partners are niche content provider, eBook retailers, tech companies, printing companies, $\mathrm{X}$ coffee shop, and also merchandise supplier. Although niche content provider stands as $\mathrm{ABC}$ Press customers, but they are the one that generates content that will be published by ABC Press and generate revenue. So, there is a mutual beneficial relationship between them. eBook retailers will help $\mathrm{ABC}$ Press in distributing their book that are in digital format. As for tech companies will provide support in developing $A B C$ Press website. Printing companies will act as the third party in fulfilling specific request from customers.

\section{Key Activities}

Proposed key activities includes niche content acquisition and production, also platform promotion, management, and maintenance. As a publisher, $\mathrm{ABC}$ Press needs contents that can add value to their customers, that is why content acquisition is one of their key activity. As for platform promotion, management, and maintenance is to support the digitization of ABC Press.

\section{Cost Structure}

Proposed cost structure are platform management and maintenance, costs of recruiting staff, operational expenses, and marketing cost.

\section{RECOMMENDATION}

Based on the Four Actions Framework and proposed Business Model Canvas, by using the blending approach, below are several recommendations to implement Long Tail Business Model combined with Multi-sided platform.

\section{Recruitment and establishment of KPI \\ (Key}

Performance Indicator)

Implementation of proposed business strategy and model will affect company's activities. This implies to several changes that the company will need regarding human resources recruited. With using the multi-sided platform and utilizing the development of internet for marketing necessity, ABC Press will need skilled human resources in IT and digital marketing. Besides that, to measure performance of employees and reduce the occurrence of inefficient key activities, ABC Press needs to establish KPI.

\section{Development of product and services}

By implementing proposed business model, ABC Press has to provide self-publishing service with a wide variety of book format and genre. Format consists of CDs, DVDs, and eBooks. As for genres, ABC Press needs to broaden genres not only for academic textbooks, they can benchmark selfpublishers like lulu.com. Besides that, ABC Press also needs to add product type that is offered, starting from photo book, comic book, magazine, yearbook, including high quality merchandise. ABC Press also can combine the current coffeeshop they have with their bookstore, so customers not only can buy books, but also buy foods and beverages.

\section{Build partnership}

By developing product and services, $\mathrm{ABC}$ Press needs to build partnership with tech companies, eBook retailers, niche content provider, printing companies, and merchandise suppliers. To develop website of ABC Press, they can work together with tech companies. Collaborating with eBook retailers can help $\mathrm{ABC}$ Press in distributing and promoting company's books. ABC Press needs to build partnership with niche content provider that provides content for book producing. As for printing companies, they can act as the third party in fulfilling particular demand for additional product, so the company doesn't need to invest in high cost machinery. Merchandise supplier can also be partner of ABC Press, to provide high quality merchandise that will be sold in the bookstore. Partnership with X coffee shop is also needed to rearrange their bookstore concept.

\section{Build IT division}

Implementation of proposed business model is highly dependent on internet and website. Because of that, $\mathrm{ABC}$ Press needs to establish IT division that is responsible in platform (e-commerce and marketplace) creation, 
management, and maintenance.

\section{Development of platform or website}

Website will become the main platform of ABC Press in facilitating niche content provider and niche customers, it will help the company in reducing inventory since Print on Demand (POD) will be applied. Several capabilities that are needed for $\mathrm{ABC}$ Press in developing their platform are provision of interactive and customized interfaces, private and secure information transaction facilities, and capability to integrate and synthesize market data.

\section{Build of channels}

ABC Press has to increase choices of channel, following the growth of marketplace. Addition of marketplace includes Shopee, Bukalapak, and Lazada. Besides that, ABC Press also has to develop their website and Google Play Books.

\section{Develop the marketing division}

By implementing the new business model, ABC Press activities will be conducted through their platform, so they will target people who are familiar with the internet. In this case, digital marketing will be an efficient way to promote their product and services.

\section{CONCLUSION}

In order to formulate business strategy and proposed new $\mathrm{BMC}$, internal and external analysis was conducted to understand strengths, weakness, opportunity, and threats that affects the company performance. Internal analysis was conducted through resources and value chain analysis. Based on both analysis it shows that ABC Press has a high number of slow-moving inventories, inefficient production process, low efforts in acquiring new customers, and weak brand. Besides that, they also lack adequate resources, whether it is human resource or machinery, and they also have a volatile revenue stream. Meanwhile, based on the external analysis, there is a demand towards digital based information, various genre and formats in the publishing industry. The growth of internet and social media penetration can generate opportunity for ABC Press in digital marketing, but margins can be threatened by technology if they do not adapt with the development. Besides that, there are also presence of substitute and a high bargaining power of buyer.

To remain competitive in the publishing industry, in the business-level strategy ABC Press should implement cost leadership strategy by generating process innovation through the development of production and distribution method. As for the business model, the company should implement long tail business model combined with multi-sided platform which focuses in offering a high number of niche products through a platform that can facilitate authors and readers to interact one another.

\section{REFERENCES}

[1] Pateli, Adamantia G., \& George M. Giaglis, "A Methodology for Business Model Evolution: Application in the Mobile Exhibition Industry," Proceedings of The Second International Conference on Mobile Business - m-Business, pp. 87-102, Vienna, 2003.

[2] Jayani, Dwi H. (September 2019). Berapa Pengguna Internet di Indonesia? [Online] Avalilable: https://databoks.katadata.co.id/datapublish/2019/09/09/berapapengguna-internet-di-

indonesia\#: :text=Proyeksi\%20Pengguna\%20Internet\%20di\%20Ind
onesia\%202017\%2D2023\&text=Data\%20Statista\%202019\%20men unjukkan\%20pengguna,yang\%20sebanyak\%2084\%20juta\%20peng guna. (Accessed: April 17 $7^{\text {th }} 2020$ ).

[3] Tian, X., \& Bill Martin, "Business Models in Digital Book Publishing: Some Insights from Australia". Publishing Research Quarterly, pp. 73-88, vol 25, 2009.

[4] Indonesian Publishers Association. (2018). Statistics: Overview of the Indonesian Publishing Industry in 2018. [Online] Available: https://www.ikapi.org/language/en/

[5] Tian, X., \& Bill Martin, "Impacting Forces on eBook Business Models Development". Publishing Research Quarterly, pp. 230-246, vol. $27,2011$.

[6] Xuemei T., Bill Martin, \& Hepu Deng, "The Impact of Digitization on Business Models for Publishing”. Journal of Systems and Information Technology, pp. 232 - 250, vol. 10 no. 3, 2008.

[7] Rappa, M. "Managing the Digital Enterprise - Business Models on the Web", Raleigh: North Carolina State University, 2001.

[8] Johnson, Mark W., Clayton M. Christensen, \& Henning Kagermann, Reinventing Your Business Model, Brighton: Harvard Business Review, 2008.

[9] Lee, Ji Hwan., Dong Ik Shin, Yong Se Kim, \& Yoo S. Hong, Business Model Design Methodology for Innovative Product - Service Systems: A Strategic and Structured Approach, New York: IEEE Computer Society, 2011.

[10] Osterwalder, A., \& Yves Pigneur, Business Model Generation: A Handbook for Visionaries, Game Changers, and Challengers, Hoboken: John Wiley \& Sons, Inc, 2010.

[11] Hitt, Michael A., R. Duane Ireland., \& Robert E. Hoskisson, Strategic Management Competitiveness \& Globalization: Concepts and Cases 12e, Bostom: Cengage Learning, 2017.

[12] Asosiasi Penyelenggara Jasa Internet Indonesia (APJII), Survei Nasional Penetrasi Pengguna Internet 2018, APJII, 2019.

[13] Badan Pusat Statistik, Statistik Gender Tematik: Profil Generasi Milenial Indonesia 2018, Jakarta: Kementerian Pemberdayaan Perempuan dan Perlindungan Anak, 2018.

[14] Hauge, Paul, The Business Models Handbook: Templates, theory and Case Studies, London: Kogan Page Limited, 2019.

[15] Wandebori, Harimukti, Manajemen Strategi dalam Perspektif Indonesia: Konsep dan Studi Kasus, Bandung: ITB Press, 2019.

[16] Wheelen, Thomas L., \& J. David Hunger, Strategic Management and Business Policy: Toward Global Sustainability, London: Pearson, 2012.

[17] Thompson, John B., Books in the Digital Age: The Transformation of Academic and Higher Education Publishing in Britain and the United States, Cambridge: Polity Press, 2005.

[18] Anderson, Chris, The Long Tail, San Fransisco: WIRED Magazine, 2004.

[19] Anderson, Chris, The Long Tail-Why the Future of Business is Selling Less of More: Longer (New Chapter: The Long Tail of Marketing), Westport: Hyperion, 2008.

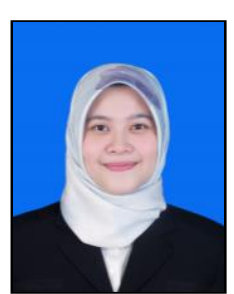

Aulia Widya Bestari Wibisono was born in Melbourne, Victoria, Australia on April $17^{\text {th }}, 1996$. She earned her bachelor degree in 2017 from Bandung Institute of Technology, majoring in Urban and Regional Planning. She is currently pursuing her master degree at Bandung Institute of Technology, majoring in Master of Business Administration. In 2016, she was in an internship program, as a Research Assistant for Spatial Planning of World Cultural Heritage Area of Bali at PT. Aria Ripta Sarana. In 2018, she became an Urban and Regional Planning Expert Assistant at PT. Amurwa International and Research Assistant for Compiling Data and Information on the Benefits of Village Funds in West Java Province. In 2019, she had an internship program at Bank Indonesia Representative Office in West Java Province in the Logistic and Facilities Management Division.

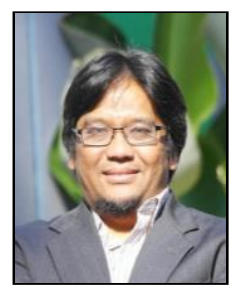

Deddy Priatmodjo Koesrindartoto earned his bachelor degree from Bandung Institute of Technology, majoring Electrical Engineering. He is an Economist by training, received a Ph. D. in Economics with a minor in Statistics, and an M.Sc. in Industrial Engineering, all from Iowa State University, United States of America.

Currently, he is an Assistant Professor at the School of Business and Management, Bandung Institute of Technology (SBM ITB). He was the former Director of Graduate Programs of Management Science in SBM ITB, 
oversees both Master and PhD Programs. Before that assignment, he served as Director of Institutional Development and Planning at SBM ITB. Prior to joining SBM ITB in 2005, He was a Research Fellow at the Center for Computational Finance and Economics Agents (CCFEA) at the University of Essex, UK. He spent three years working for energy services industries before pursuing graduate studies.

He has many publications in journals and conference proceeding with fields such as Financial Economics, Behavioral Finance, Computational Finance, Market Design, Agent-based Modeling, Applied Microeconomics, Banking Industry and Financial Stability, Electricity Markets, Market Microstructure, Big Data Analytics, Fintech. 